\title{
EFFECTS OF RED DRAGON FRUIT (Hylocereus polyrhizus) SKIN EXTRACT ON LEAD ACETATE TOXICITY IN THE MORPHOLOGY OF Balb/c MICE (Mus musculus) SPERMATOZOA
}

\author{
Rahmawati Raharjo ${ }^{1}$, Sri Agus Sudjarwo ${ }^{2}$, Reny I'tishom ${ }^{3}$ \\ ${ }^{1}$ Master Program of Reproductive Health Science, Faculty of Medicine, ${ }^{2}$ Department of Pharmacology, Faculty of \\ Veterinary Medicine, ${ }^{3}$ Department of Medical Biology, Faculty of Medicine, Universitas Airlangga
}

\begin{abstract}
ABSTRAK
Ekstrak kulit buah naga merah digunakan sebagai antioksidan terhadap toksisitas timbal asetat. Penelitian ini bertujuan untuk membuktikan perbedaan morfologi spermatozoa testis mencit yang dipapar timbal asetat. Dua puluh lima ekor mencit dibagi menjadi 5 kelompok (5 ekor mencit per kelompok). Kelompok K-adalah kelompok kontrol tanpa pemberian timbal asetat dan ekstrak kulit buah naga, kelompok $\mathrm{K}+$ adalah kelompok dengan pemberian timbal asetat $8 \mathrm{mg} / \mathrm{KgBB}$ selama 14 hari, kelompok P1 adalah kelompok perlakuan dengan pemberian timbal asetat $8 \mathrm{mg} / \mathrm{KgBB}$ selama 14 hari + ekstrak kulit buah naga merah $250 \mathrm{mg} / \mathrm{kgBB}$ selama 21 hari, kelompok P2 adalah kelompok perlakuan dengan pemberian timbal asetat $8 \mathrm{mg} / \mathrm{KgBB}$ selama 14 hari + ekstrak kulit buah naga merah $500 \mathrm{mg} / \mathrm{kgBB}$ selama 21 hari, dan kelompok P3 adalah kelompok perlakuan dengan pemberian timbal asetat 8 $\mathrm{mg} / \mathrm{KgBB}$ selama 14 hari + ekstrak kulit buah naga merah $1000 \mathrm{mg} / \mathrm{kgBB}$ selama 21 hari. Hasil penelitian menunjukkan bahwa terdapat perbedaan signifikan $(P<0,05)$ pada morfologi spermatozoa normal antara kelompok $K-, K_{+}, P 1, P 2$, dan P3. Sebagai simpulan, pemberian ekstrak kulit buah naga merah dosis $500 \mathrm{mg} / \mathrm{kgBB}$ (P2) merupakan dosis optimal yang dapat digunakan sebagai terapi untuk meningkatkan motilitas, morfologi, dan konsentrasi spermatozoa mencit yang dipapar timbal asetat. (FMI 2017;53:237-241)
\end{abstract}

Kata kunci: Timbal asetat; ekstrak kulit buah naga merah; spermatozoa; motilitas; morfologi spermatozoa

\begin{abstract}
Red dragon fruit skin extract is used as an antioxidant to lead acetate toxicity. This study aimed to prove the difference in morphology of mice testicular spermatozoa exposed to lead acetate. Twenty-five mice were divided into 5 groups (5 mice per group). $K$ - group was the control group without lead acetate and dragon fruit skin extract administration, $K+$ group was treated with 8 $\mathrm{mg} / \mathrm{KgBW}$ lead acetate administration for 14 days, $P 1$ group was treated with the administration of $8 \mathrm{mg} / \mathrm{KgBW}$ lead acetate for 14 days $+250 \mathrm{mg} / \mathrm{kgBW}$ red dragon fruit skin extract for 21 days, $P 2$ group was treated with the administration of $8 \mathrm{mg} / \mathrm{Kg} B W$ lead acetate for 14 days $+500 \mathrm{mg} / \mathrm{kgBW}$ red dragon fruit skin extract for 21 days, and group P3 was a treatment group with the administration of $8 \mathrm{mg} / \mathrm{KgBW}$ lead acetate for 14 days $+1000 \mathrm{mg} / \mathrm{kgBW}$ red dragon fruit extract for 21 days. The results showed that there was significant difference $(P<0.05)$ in normal sperm morphology among $K-, K+, P 1, P 2$, and $P 3$. In conclusion, the administration of red dragon skin extract at a dose of $500 \mathrm{mg} / \mathrm{kgBW}(P 2)$ is the optimal one which can be used as therapy to increase motility, morphology, and concentration of mice spermatozoa exposed to lead acetate. (FMI 2017;53:237-241)
\end{abstract}

Keywords: Lead acetate; red dragon fruit skin extract; spermatozoa; motility; morphology of spermatozoa

Correspondence: Rahmawati Raharjo, Master of Reproductive Health Science Program, Faculty of Medicine, Universitas Airlangga, Jl. Prof Moestopo 47, Surabaya 60131. Phone: 081252724717. Email:

raharjorahmawati@yahoo.co.id

\section{INTRODUCTION}

Air pollution in big cities is getting worse. Seventy to eighty percent of the air pollution is caused by emission of motor vehicle exhaust (Maryanto et al 2009, Rangkuti 2004). Motor vehicles produce exhaust emissions of hydrocarbons, nitrogen oxides, carbon monoxide, photochemical oxides, and lead (Mahawati 2011). Lead, apart from exhaust emissions, can also be found in battery manufacturers, fuel-burning industries, printing, water pipes, insecticides, paints, lead-containing cosmetics, and others (Chowdhury 2009, Sharma \&
Garu 2011). Lead can enter the body through various ways such as respiration, gastrointestinal tract and skin contact (Laila and Sofwati 2013). Lead can cause health problems in humans even in levels lower than the maximum blood levels allowed (Hasan 2012). Exposure to lead in the long term will accumulate in the body so it can cause various abnormalities. In male reproductive system, the accumulation of lead exposure can decrease libido, decrease the number of spermatozoa and cause abnormal morphology of spermatozoa, resulting in infertility (Panggabean et al 2008). 
Lead may also catalyze the formation of ROS. ROS production is triggered by an increase in ALA because lead inhibits ALAD (aminolevulinic acid dehydrogenase) enzyme. The formed ROS results in decreased activity of antioxidant enzymes in the body, such as glutathione peroxidase, catalase, and superoxide dismu-tase (Al-Masri, 2015). ROS is able to directly damage spermatozoa DNA, initiate apoptosis in spermatozoa, and activate the caspase enzyme to degrade spermatozoa DNA (Yulianto et al 2013, Rong-zhen et al 2013). Mitochondrial damage by ROS causes abnormal spermatozoa cells to have apopotosis (Makker et al 2009).

The sources of antioxidants can be either synthetic or natural ones. However, nowadays, the use of synthetic antioxidants begins to be limited because natural antioxidants have been recognized as better than synthetic ones because of their low cytotoxic and residual effects (Rong-zhen et al 2013). One of antioxidant-producing fruit which has been observed is red dragon fruit. Red dragon fruit skin has high antioxidant content when compared with its fruit flesh, such as phenolic, flavonoids, and polyphenols (Wu et al 2006). The polyphenols and flavonoids contained in red dragon fruit's methanol extract are five times higher than those in its fruit flesh (Kim et al 2011). Nurliyana et al (2010) proved that the content of phenolic compound on red dragon fruit skin was $28.16 \mathrm{mg} / 100 \mathrm{~g}$ while for the flesh was only $3.75 \mathrm{mg} / 100 \mathrm{~g}$. Free radical binding activities conducted with IC50 technique also showed that red dragon fruit skin had the highest free radical binding activity. Thus, further study on the benefits of red dragon fruit skin as a natural source of antioxidants to improve morphology of spermatozoa in Balb/c Strain mice (Mus musculus) exposed to lead acetate is needed.

\section{MATERIALS AND METHODS}

This was a pure experimental study using post-test only control group design. This study was conducted in Biochemistry and Medical Biology Laboratories, Faculty of Medicine, Universitas Airlangga. This study was conducted from April to June 2016. This study received the certificate of Ethical Clearance from Faculty of Medicine, Universitas Airlangga. The samples used in this study were male mice (Mus musculus) aged 8-10 weeks, with weight ranging from 25-30 grams and healthy characterized by agile movement and good appetite. Animal testing was acclimatized by being caged for one week.

The number of samples required by calculation was 25 mice divided into 5 groups. The first group was negative control group, the second was negative control group with the administration of $8 \mathrm{mg} / \mathrm{kg} \mathrm{BW}$ lead acetate, the third was treatment group I with the administration of 8 $\mathrm{mg} / \mathrm{kgBW}$ lead acetate and $250 \mathrm{mg} / \mathrm{kgBW}$ dragon fruit skin extract, the fourth was treatment group II with the administration of $8 \mathrm{mg} / \mathrm{kgBW}$ lead acetate and 500 $\mathrm{mg} / \mathrm{kgBW}$ dragon fruit skin extract, and the fifth was treatment group III with the administration of 8 $\mathrm{mg} / \mathrm{kgBW}$ and $1000 \mathrm{mg} / \mathrm{kgBW}$ dragon fruit skin extract. The administration of lead was given by peritonial injection at a dose of $8 \mathrm{mg} / \mathrm{kgBW}$ once per day for 14 days, and the administration of red dragon fruit extract was given orally for 21 days starting from day 15 .

The mice were sacrificed with decapitation. Then, each mouse was incised on the abdominal wall and their testes, vas deferens, and epididymis were removed. Mice with removed organs were then buried. The epididymis and vas deferens of the mice were further excreted in PBS solution and fed into a $\mathrm{CO} 2$ incubator for 15 minutes, then were stirred well. The spermatozoa morphological examination was also performed.

The counting was performed on abnormally shaped spermatozoa with circular tail and broken head, then the results were compared to the number of spermatozoa present in the visual field and expressed in percent. The observation was performed under a microscope with an objective magnification of 400 times.

The measurement data were analyzed to determine the frequency distribution including mean and SD on sperm motility and morphology. Furthermore, the results were analyzed using one way Anova test if it had normal distribution. If not, then the alternative test of KruskalWallis test was used. The results were significant if $\mathrm{p}<0.05$, indicating that at least there was a significant difference between the groups. To find which groups differ significantly, post-hoc analysis was performed.

\section{RESULTS}

\section{Effects of red dragon fruit extract on normal spermatozoa morphology of mice exposed to lead acetate}

Normal spermatozoa morphological data were presented in the form of mean and standard deviation as shown in Table 1. To assess data distribution, Saphiro-Wilk test was used. Whereas, to assess data variance, Bartlett test was used. The data distribution was normal and the variance was homogeneous if $\mathrm{p}>0.05$. 
Table 1. Mean, distribution, and variance of normal spermatozoa morphological data

\begin{tabular}{cccccc}
\hline Samples & Mean & $\begin{array}{c}\text { The p value of } \\
\text { data distribution }\end{array}$ & Note & $\begin{array}{c}\text { The p value of } \\
\text { data variant }\end{array}$ & Note \\
\cline { 1 - 5 } K1 & $42.0 \pm 3.61$ & 0.062 & $\begin{array}{c}\text { Normal } \\
\text { distribution }\end{array}$ & 0.538 & Homogenous \\
P1 & $14.0 \pm 6.20$ & & & & \\
P2 & $31.0 \pm 6.67$ & & & & \\
P3 & $36.4 \pm 5.68$ & & & \\
P4 & $32.4 \pm 3.05$ & & & \\
\hline
\end{tabular}

Table 1 shows that normal spermatozoa morphology has normal data distribution and the variance of homogeneous data, so it qualifies for testing using One Way Anova test, followed by Post-Hoc Bonferroni analysis.

Table 2. The results of the one-way Anova variance analysis of normal spermatozoa morphology

\begin{tabular}{ccc}
\hline Variable & $\mathrm{p}$ Value & Note \\
\hline $\begin{array}{c}\text { Normal spermatozoa } \\
\text { morphology }\end{array}$ & 0.001 & Significant \\
\hline
\end{tabular}

The results of one-way Anova test showed $p$ value $<0.05$, so there was significant difference in normal sperm morphology between $\mathrm{K}-, \mathrm{K}+, \mathrm{P} 1, \mathrm{P} 2$, and P3 groups. The Bonferroni Post Hoc test was then performed to determine the normal morphology of normal spermatozoa among groups.

Table 3. Results of post hoc Bonferroni morphological test of normal spermatozoa

\begin{tabular}{ccccc}
\hline Groups & $\mathrm{K}-$ & $\mathrm{K}+$ & $\mathrm{P} 1$ & $\mathrm{P} 2$ \\
\hline $\mathrm{K}+$ & $0.001 *$ & & & \\
$\mathrm{P} 1$ & $0.034^{*}$ & $0.001 *$ & & \\
$\mathrm{P} 2$ & 1.000 & $0.001 *$ & 1.000 & \\
$\mathrm{P} 3$ & 0.089 & $0.000 *$ & 1.000 & 1.000 \\
\hline *Significant if $\mathrm{p}<0.05$ & & &
\end{tabular}

The analysis of normal spermatozoa morphological data using Post Hoc Bonferroni test showed that normal morphology of normal spermatozoa which was significant with $\mathrm{p}<0.05$ were in $\mathrm{K}$ - group and $\mathrm{K}+$ group, $\mathrm{K}$ group and $\mathrm{P} 1$ group, $\mathrm{K}+$ group and $\mathrm{P} 1$ group, $\mathrm{K}+$ group and $\mathrm{P} 2$ group, and $\mathrm{K}+$ group and $\mathrm{P} 3$ group.

The results of the data analysis showed that normal spermatozoa morphology in the positive control group $(\mathrm{K}+)$ decreased when compared with negative control group (K-). The morphology of normal spermatozoa in the three treatment groups $(\mathrm{P} 1, \mathrm{P} 2$, and $\mathrm{P} 3)$ decreased when compared with the negative control group (K-), but increased compared to the positive control group (K + ). This means that the provision of red dragon fruit skin extract can increase the morphology of normal spermatozoa exposed to lead acetate. The average of normal spermatozoa morphology can be seen in Fig. 1.

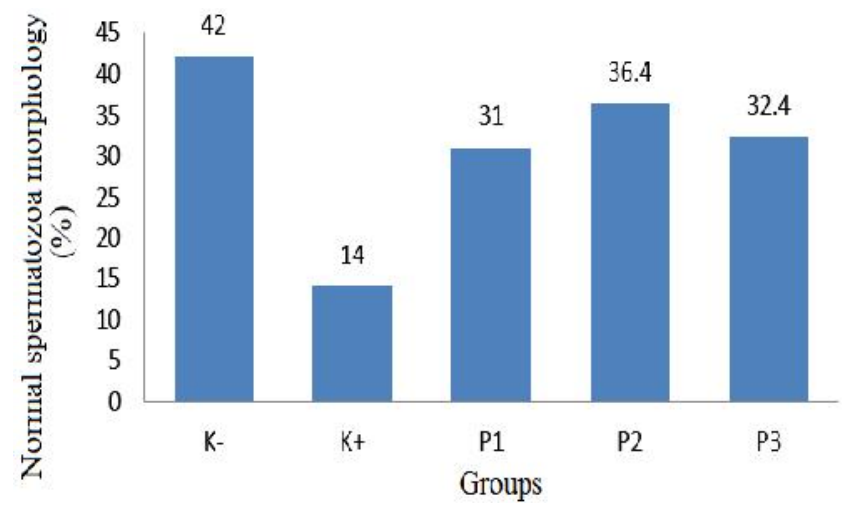

Fig. 1. Percentage comparison of normal spermatozoa of groups $\mathrm{K}-, \mathrm{K}+, \mathrm{P} 1, \mathrm{P} 2$, and $\mathrm{P} 3$. The percentage of normal spermatozoa morphology in group P1 had the lowest percentage followed by group P3 then P2, while group P2 had the highest percentage.

\section{DISCUSSION}

The results of this study indicated that there was difference in the morphology of spermatozoa between negative control group (K-) and positive control group $(\mathrm{K}+)$ exposed to lead acetate. The $\mathrm{K}+$ group had normal spermatozoa morphology compared to the $\mathrm{K}$ - group. Lead has toxic effect on the male reproductive system that can lower the morphology of normal spermatozoa. These toxic effects emerge since lead can produce ROS and decrease reserved endogenous antioxidants that cause the state of oxidative stress. The state of oxidative stress can occur at the central and testicular levels. At the central level of the pituitary axis hypothalamus, lead can block the secretion of norepinephrin thus suppressing GnRH secretion. Decreased GnRH secretion may interfere with the spermatogenesis process because the levels of the hormone FSH and LH decrease, thus affecting the quality of spermatozoa produced by the testes. 
A dose of $8 \mathrm{mg} / \mathrm{kgBW}$ lead administration intraperitonally for 2 weeks decreased the morphology of normal spermatozoa. This study is in line with Al-Shaikh et al (2013) study of $8 \mathrm{mg} / \mathrm{kg} \mathrm{BW}$ of lead acetate for 2 weeks that showed testicular histologic damage, reduced number, activity and morphology of spermatozoa when compared to control group. Another study conducted by Acharya et al (2003) proved that the administration of lead acetate with a single dose of $200 \mathrm{mg} / \mathrm{kgBW}$ increased abnormal morphology of spermatozoa and decreased sperm count. The mechanism of free radical formation begins when the lead is absorbed by the body through inhalation and then into blood circulation system. In blood circulation system, lead affects hematology system because it will inhibit heme synthesis enzyme, the d-aminolevulinic acid dehydratase (dALAD), resulting in a decrease in heme production. This decrease in heme production will increase ALA synthetase activity, and eventually ALA production increases. Increased ALA leads to the formation of ROS (Hotz et al 2003).

If the amount of free radicals or ROS in the body exceeds the endogenous antioxidant capabilities, such as glutathione peroxidase, catalase, and superoxide dismutase, the body has no defense mechanisms against oxidative stress states (Werdhasari 2014). A study conducted by Algawish and Abdelrazek (2014) showed that there was a significant decrease in antioxidant enzyme activity ie SOD enzyme and catalase in mice exposed to lead.

When the process of normal spermatogenesis takes place, the mechanism of apoptosis serves to regulate the balance of Sertoli and germ cell cells, and helps to eliminate abnormal spermatozoa. However, when apoptosis increases, it may cause malfunction of male reproductive function characterized by spermatogensesis disorder and a large decrease in the number of spermatogenic cells, which affects on the decrease in spermatozoa and increased abnormal morphology of spermatozoa (Lamando et al 2014). Excessive apoptosis is caused by the release of C-cotoxrome proteins, caspases 9 and 3. The release of the three proteins suggests that mitochondrial damage (loss of transmembrane permeability, and cytochrome c release that leads to electron transport interference) is due to increased ROS exposure (Wang et al 2003).

The results of this study indicated that red dragon fruit skin extract may increase motility and decrease the amount of abnormal morphology of spermatozoa, especially in group P2. Oxidative stress in blood and testicular tissue caused by lead induction may be inhibited by compounds contained in red dragon fruit skin extracts. Red dragon fruit skin extract contains phenolic, flavonoids, and polyphenols (Wu et al 2006). Phenolics, flavonoids, and polyphenols are primary antioxidants. Primary antioxidants act to bind free radicals to inhibit chain initiation and to break the propagation chains due to the presence of hydrogen or electron atom donors, thereby converting them into more stable products.

Flavonoids are effective as scavengers of hydroxyl and peroxyl radicals. Flavonoids (flavonoids-OH) are reported to act as peroxyl radical scavengers ( $\left.\mathrm{ROO}^{*}\right)$ to be regenerated into $\mathrm{ROOH}$, and act as scavengers of hydroxyl radicals $\left(\mathrm{OH}^{*}\right)$ to be regenerated into $\mathrm{H} 2 \mathrm{O}$. The resultant compounds of peroxyl and hydroxyl radical regenerations are more stable, so they are not easy to engage in other radical reactions (Lee et al 2004).

This study showed that P3 group had normal morphology percentage of spermatozoa, which was lower than that in P2. This means that higher dose is not directly proportional to normal spermatozoa morphology. The antioxidant dose administered may affect the rate of oxidation. The administration of antioxidants at high concentrations will actually change the antioxidant into pro-oxidant which means that the antioxidant is no longer functioning as an antidote to free radicals. Here the process of antioxidants turns into pro-oxidant (Iswara 2010):

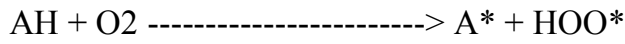

$$
\begin{aligned}
& \mathrm{AH}+\mathrm{ROOH} \text {----------------> RO* + } \mathrm{H} 2 \mathrm{O}+\mathrm{A}^{*}
\end{aligned}
$$

\section{CONCLUSION}

The administration of red dragon skin extract at a dose of $500 \mathrm{mg} / \mathrm{kgBW}$ (P2) is the optimal dose which can be used as therapy to increase motility, morphology, and concentration of mice spermatozoa exposed to lead acetate.

\section{REFERENCES}

Acharya UR, Acharya S, Misrhra (2003). Lead acetate induced cytotocity in male germinal cells of swiss mice, Industrial Health 41, 291-294

Al-Masri SA (2015). Effect of pumpkin oil and vitamin e on lead induced testiscular toxicity in male rats. The Journal of Animal \& Plant Sciences 25, 72-77

Al-Shaikh MN, Wahab A, Tala AL, Kareem SHA (2013). Protective effect of chufa tubers (cyperus esculentus) on induction of sperm abnormalities in mice treated with lead acetate. International Journal of Drug development \& Research 5, 387-392 
Chowdhury AR (2009). Recent advances in heavy metals induced effect on male reproduvtive function-a retrospective. Al Ameen Journal Medicine Science 2, $37-42$

Hasan W (2012). Pencegahan keracunan timbal kronis pada pekerja dewasa dengan suplemen kalsium. Makara Kesehatan 16, 1-8

Hotz C, Peerson JM, Brown KH (2003). Suggested lower cutoffs of serum zinc concentrations for assessing zinc status: reanalysis of the second national health and nutrition examination survey data (19761980). Am Journal Clinical Nutrition 78, 756-764

Iswara RAFW (2010). Pengaruh pemberian ekstrak daun Cyclea barbata L. miers terhadap motilitas spermatozoa mencit balb/c jantan yang dipapar asam rokok, Artikel Karya Tulis Ilmiah, Denpasar, Universitas Udayana

Kim H, Choi HK, Moon JY, et al (2011). Comparative antioxidant and antiproliferative activities of red and white pitayas and their correlation with flavonoid and polyphenol content. Journal of Food Science 76, C3845

Laila NN, Shofwati I (2013). Kadar timbal dalam darah dan keluhan kesehatan pada operator wanita SPBU. Jurnal Kesehatan Reproduksi 4, 41-49

Lamando D, Soegianto A, Abadi A, Keman S (2014). Antioxidant effects of sarang semut (Myrmecodia pendans) on the apoptosis of spermtogenic cells of rats exposed to plumbum. Research Journal of Pharmaceutical, Biological and Chemical Sciences 5, 282294

Lee J, Koo N, Min DB (2004). Reactive oxygen species, aging, and antioxidative nutraceuticals. Compre Rev. in Food Sci. and Food Safety 3, 21-33

Mahawati E (2011). Faktor-faktor resiko paparan timbal. Jurnal Visikes 10, 131-138
Makker K, Agarwal A, Sharma R (2009). Oxidative stress \& male infertility. Indian J Med Res 129, 357367

Maryanto D, Mulasari SA, Suryani D (2009). Penurunan kadar emisi gas buang karbon monoksida (CO) dengan penambahan arang aktif pada kendaraan bermotor di Yogyakarta. Kes Mas 3, 198-205

Nurliyana R, Zahir IS, Suleiman KM, Aisyah MR, Rahim KK (2010). Antioxidant study of pulps and peels of dragon fruits: a comparative study. International Food Research Journal 17, 367-375

Panggabean PCT, Sylvia S, July I (2008). Efek pajanan timbal terhadap infertilitas pria. JKM 8, 87 - 93

Rangkuti MNS (2004). Kandungan logam berat timbal dalam daun dan kulit kayu tanaman kayu manis (Cinnamomum burmani $B l$ ) pada sisi kiri jalan tol Jagorawi. B i o S MART 6, 143-146

Rong-zhen Z, Dao-wei Z (2013). Oxidative stress and role of natural plant derived antioxidants in animal reproduction. Journal of Inyegrative Agriculture 12, 1826-1838

Sharma R, Garu U (2011). Effects of lead toxicity on developing testes in swiss mice. Universal Journal of Enviromental Research and Technology 1, 390-398

Wang X, Sharma RK, Sikka SC, Thomas AJ, Falcone T, Agarwal A (2003). Oxidarive stress is associated with increased apoptosis leading to spermatozoa DNA damage in patient with male factor infertility. Fertility and Sterility $80,531-535$

Werdhasari A (2014). Peran antioksidan bagi kesehatan. Jurnal Bioetik Medisiana Indonesia 3, 59-68

Wu L, Hsu HW, Chen YC, Chiu CC, Lin YI, Ho JA (2006). Antioxidant and antiproliferative activities of red pitaya. Food Chemistry 95, 319-327

Yulianto RA, Isnaini W, Susanti R (2013). Pengaruh pemberian vitamin $\mathrm{E}$ terhadap kualitas sperma tikus putih yang dipapar timbal. Unnes Journal Life Science 2, 92-99 